
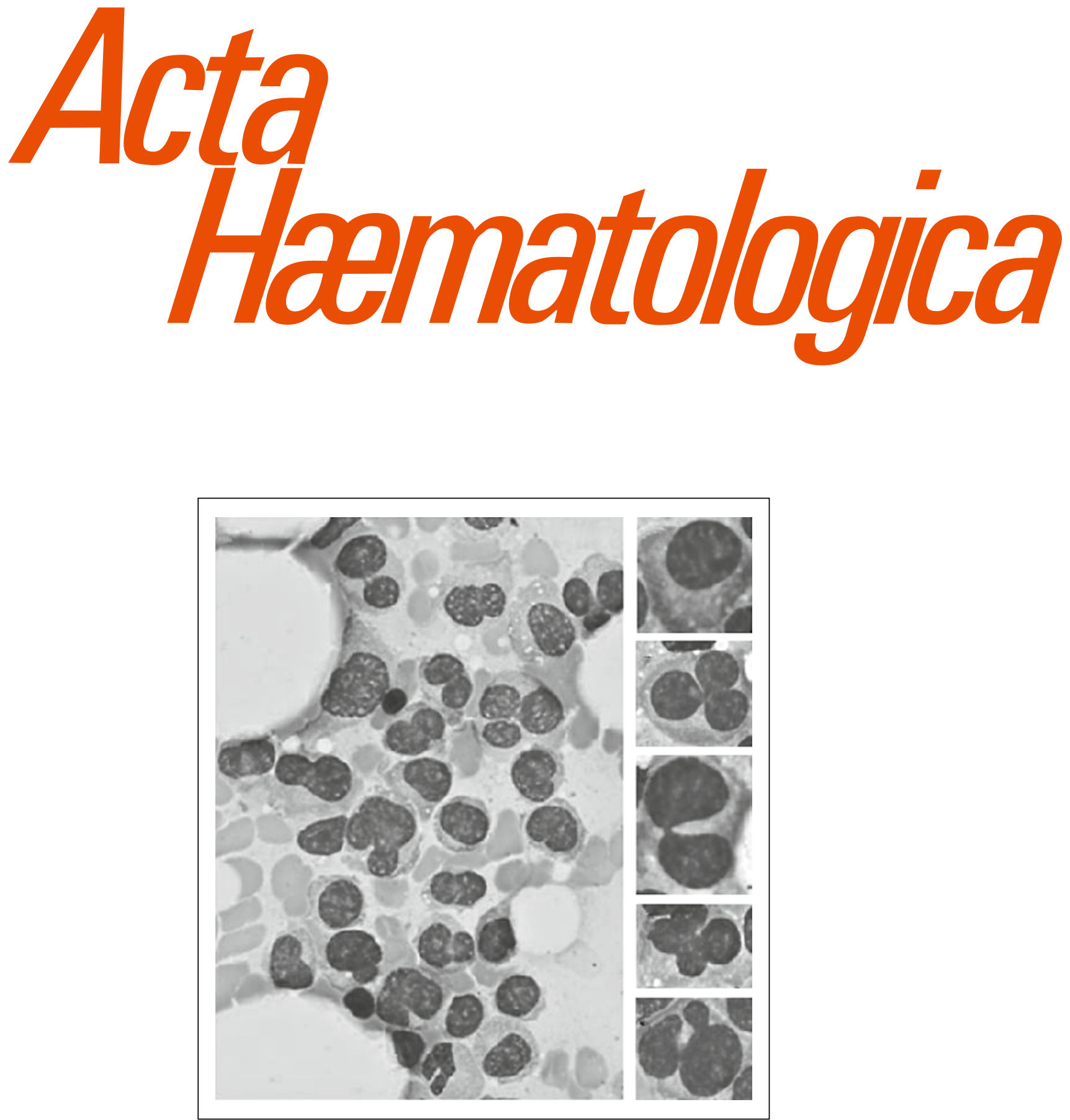

S. Karger

Medical and Scientific Publishers $\mathrm{KA} R \mathrm{R}$ E R Basel · Freiburg · Paris .

London - New York .

New Delhi · Bangkok · Beijing ·

Tokyo $\cdot$ Kuala Lumpur .

Singapore $\cdot$ Sydney 


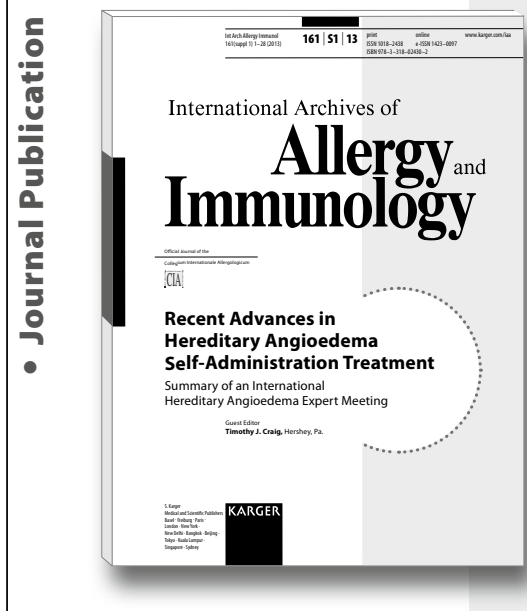

Recent Advances in Hereditary Angioedema Self-Administration Treatment

Summary of an International Hereditary

Angioedema Expert Meeting

Editor: Timothy J. Craig (Hershey, Pa.)

IV + 28 p., 6 color fig., 13 tab., soft cover, 2013

CHF 29.- / EUR 24.- / USD 34.00 (soft cover)

CHF 35.- / EUR 29.- / USD 41.00 (online)

Online version for institutional purchase

Prices subject to change

EUR price for Germany, USD price for USA only

ISBN 978-3-318-02430-2

e-ISBN 978-3-318-02431-9

Supplement Issue

International Archives of Allergy

and Immunology

Vol. 161, Suppl. 1 (2013)

Included in subscription

Listed in MEDLINE/PubMed

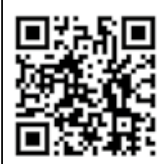

Dear Librarian

I have reviewed this publication and

would like to recommend it for our library.

Recommended by:

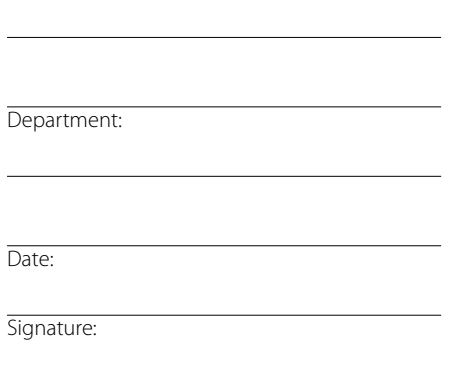

Orders may be placed with any bookshop,

\section{Recent Advances in}

Hereditary Angioedema

Self-Administration Treatment

Summary of an International Hereditary

Angioedema Expert Meeting

Editor

Timothy J. Craig

\section{Contents}

Foreword

- Recent Advances in Hereditary Angioedema Self-Administration

Treatment: Summary of an International Hereditary

Angioedema Expert Meeting: Craig, T.J.

\section{Review}

- Review of Recent Guidelines and Consensus Statements on

Hereditary Angioedema Therapy with Focus on

Self-Administration: Cicardi, M.; Craig, T.J.; Martinez-Saguer, I.;

Hébert, J.; Longhurst, H.J.

\section{Original Papers}

- Current Status of Implementation of Self-Administration

Training in Various Regions of Europe, Canada and the USA in the Management of Hereditary Angioedema: Caballero, T.; Sala-Cunill, A.; Cancian, M.; Craig, T.J.; Neri, S.; Keith, P.K.;

Boccon-Gibod, I.; Bethune, C.; Bork, K.

- Practical Approach to Self-Administration of Intravenous C1-INH Concentrate: A Nursing Perspective: Symons, C.; Rossi, 0.; Magerl, M.; Andritschke, K.

- Challenges of C1-Inhibitor Concentrate Self-Administration: Boysen, H.B.; Bouillet, L.; Aygören-Pürsün, E.

\section{Summary}

- Recent Advances in Hereditary Angioedema Self-Administration Treatment: Summary of an International Hereditary Angioedema Expert Meeting: Craig, T.J.

Author Index/Subject Index

\section{The easiest way to order: www.karger.com/iaa}

Karger - Medical and Scientific Publishers

$\mathrm{CH}-4009$ Basel, Switzerland

orders@karger.com, f: +41 613061234

www.karger.com 


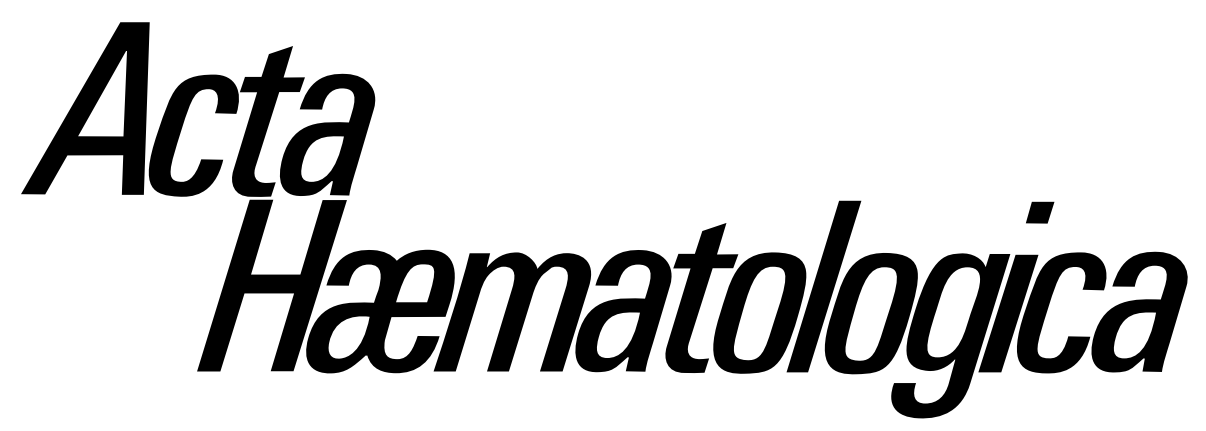

Founded 1948 by E. Meulengracht, K. Rohr, and G. Rosenow

Continued by H. Lüdin (1960-1977), U. Bucher (1977-1983), R.S. Hillman (1978-1987),

H.R. Marti (1983-1988), E.A. Beck (1984-1988), B. Ramot (1989-1995)

\section{Editor-in-Chief}

I. Ben-Bassat, Qiryat-Ono

\section{Associate Editor}

R.C. Tait, Glasgow

\section{Editorial Board}

B. Bain, London

T. Barbui, Bergamo

A.M. Carella, Genova

M. Coleman, New York, NY

D. Dilloo, Bonn

F. Di Raimondo, Catania

R.P. Gale, London

G. Henze, Berlin

C. Hershko, Jerusalem

A.V. Hoffbrand, London

H. Kanno, Tokyo
G. Konwalinka, Innsbruck

A. Kulozik, Heidelberg

V. Liso, Bari

M. Makris, Sheffield

P.M. Mannucci, Milan

C. Nissen, Basel

P. Raanani, Ramat-Aviv

S.C. Raimondi, Memphis, TN

M. Stern, Basel

A. Tefferi, Rochester, MN
Printed in Switzerland on acid-free and non-aging paper (ISO 9706) by Reinhardt Druck, Basel
Appears 6-weekly: 2 volumes per year (8 issues) 


\section{Submission}

Manuscripts written in English should be submitted using the online submission website at:

www.karger.com/aha

Should you experience any problems with your submission, please contact:

aha@karger.com
Prof. I. Ben-Bassat
S. KARGER AG
Editorial Office 'Acta Haematologica'
PO Box
CH-4009 Basel (Switzerland)

All manuscripts must be accompanied by a covering letter signed by all authors. Assurance should be given that the manuscript is not under simultaneous consideration by any other publication. The preferred word processing package is Word for Windows ${ }^{\circledR}$. Presentation of manuscripts should conform with the Uniform Requirements for Manuscripts Submitted to Biomedical Journals (see N Engl J Med 1997;336:309-315).

\section{Conditions}

All manuscripts are subject to editorial review. Manuscripts are received with the explicit understanding that they are not under simultaneous consideration by any other publication. Submission of an article for publication implies the transfer of the copyright from the author to the publisher upon acceptance. Accepted papers become the permanent property of Acta Haematologica and may not be reproduced by any means, in whole or in part, without the written consent of the publisher. It is the author's responsibility to obtain permission to reproduce illustrations, tables, etc. from other publications.

\section{Arrangement}

Recommendation for Usage of Units and Abbreviations: The standard abbreviations used for measurements of weight, length, volume, and time (i.e. $\mathrm{mg}, \mathrm{cm}, \mathrm{ml}, \mathrm{min}$ ) are used without definition. The abbreviations listed on the opposite page also require no definition. Please note that punctuation is not needed. The usage of units as recommended in the table on the opposite page is required. When listed the alternative units can be used.

Title page: The first page of each paper should indicate the title, the authors' names, the institute where the work was conducted, and a short title for use as running head. Full address: The exact postal address of the corresponding author complete with postal code must be given at the bottom of the title page. Please also supply phone and fax numbers, as well as e-mail address.

Key words: Please supply 3-10 key words in English that reflect the content of the paper.

Abstract: Each paper needs an abstract of a maximum of 200 words.

Footnotes: Avoid footnotes. When essential, they are numbered consecutively and typed at the foot of the appropriate page.

Tables and illustrations: Tables and illustrations (both numbered in Arabic numerals) should be prepared on separate sheets. Tables require a heading and figures a legend, also prepared on a separate sheet. For the reproduction of illustrations, only good drawings and original photographs can be accepted; negatives or photocopies cannot be used. Due to technical reasons, figures with a screen background should not be submitted. When pos- sible, group several illustrations on one block for reproduction (max. size $180 \times 223 \mathrm{~mm}$ ) or provide crop marks. On the back of each illustration, indicate its number, the author's name, and 'top' with a soft pencil. Electronically submitted b/w half-tone and color illustrations must have a final resolution of $300 \mathrm{dpi}$ after scaling, line drawings one of $800-1,200 \mathrm{dpi}$.

\section{Color illustrations}

Online edition: Color illustrations are reproduced free of charge. In the print version, the illustrations are reproduced in black and white. Please avoid referring to the colors in the text and figure legends.

Print edition: Up to 6 color illustrations per page can be integrated within the text at CHF 800.- per page.

References: In the text identify references by Arabic numerals [in square brackets]. Material submitted for publication but not yet accepted should be noted as [unpublished data] and not be included in the reference list. The list of references should include only those publications which are cited in the text. Do not alphabetize; number references in the order in which they are first mentioned in the text. The surnames of the authors followed by initials should be given. There should be no punctuation other than a comma to separate the authors. Please cite all authors, 'et al' is not sufficient. Abbreviate journal names according to the Index Medicus system. Also see International Committee of Medical Journal Editors: Uniform requirements for manuscripts submitted to biomedical journals (www.icmje.org)

\section{Examples}

(a) Papers published in periodicals: Sun J, Koto H, Chung KF: Interaction of ozone and allergen challenges on bronchial responsiveness and inflammation in sensitised guinea pigs. Int Arch Allergy Immunol 1997;112:191195.

(b) Papers published only with DOI numbers:

Theoharides TC, Boucher W, Spear K: Serum interleukin-6 reflects disease severity and osteoporosis in mastocytosis patients. Int Arch Allergy Immunol DOI: $10.1159 / 000063858$

(c) Monographs: Matthews DE, Farewell VT: Using and Understanding Medical Statistics, ed 3, revised. Basel, Karger, 1996.

(d) Edited books: Parren PWHI, Burton DR: Antibodies against HIV-1 from phage display libraries: Mapping of an immune response and progress towards antiviral immunotherapy; in Capra JD (ed): Antibody Engineering. Chem Immunol. Basel, Karger, 1997, vol 65, pp 18-56.

Reference Management Software: Use of EndNote is recommended for easy management and formatting of citations and reference lists.

\section{Rapid Communication}

Manuscripts intended for rapid communication mus present new findings of sufficient importance to justify their accelerated acceptance. They should follow the general arrangement of research papers except that the separate sections should not be formally titled. They should not be more than three pages in length (including figures, tables and references). Proofs are checked by the Main Editor and not sent to the authors. Review will be rapid, and once accepted, the paper will be included in the next planned issue. If manuscripts require significant change after editing they will be treated as brief communications and returned to the authors for correction.

\section{Brief Communication}

The general arrangement for brief communications is the same as for research papers except that the man- uscript is not divided into separate sections formally entitled introduction, methods, results, discussion. No abstract is required. These should not be more than 3 pages in length.

\section{Letter to the Editor}

Comments and responses to previously published articles and other short correspondences are welcome. They should be limited to 1 or $1 \frac{1}{2}$ manuscript pages with a general arrangement as specified for Brief Communications.

\section{Digital Object Identifier (DOI)}

S. Karger Publishers supports DOIs as unique identifiers for articles. A DOI number will be printed on the title page of each article. DOIs can be useful in the future for identifying and citing articles published online without volume or issue information. More information can be found at www.doi.org.

\section{Supplementary Material}

Supplementary material is restricted to additional data that are not necessary for the scientific integrity and conclusions of the paper. Please note that all supplementary files will undergo editorial review and should be submitted together with the original manuscript. The Editors reserve the right to limit the scope and length of the supplementary material. Supplementary material must meet production quality standards for Web publication without the need for any modification or editing. In general, supplementary files should not exceed $10 \mathrm{Mb}$ in size. All figures and tables should have titles and legends and all files should be supplied separately and named clearly. Acceptable files and formats are: Word or PDF files, Excel spreadsheets (only if the data cannot be converted properly to a PDF file), and video files (.mov, .avi, .mpeg).

\section{Author's Choice ${ }^{\mathrm{TM}}$}

Karger's Author's Choice ${ }^{\mathrm{TM}}$ service broadens the reach of your article and gives all users worldwide free and full access for reading, downloading and printing at www. karger.com. The option is available for a one-time fee of CHF 3,000.-, which is a permissible cost in grant allocation. More information can be found at www.karger. com/authors_choice.

\section{NIH-Funded Research}

The U.S. National Institutes of Health (NIH) mandates under the NIH Public Access Policy that final, peer-reviewed manuscripts appear in its digital database within 12 months of the official publication date. As a service to authors, Karger submits the final version of your article on your behalf to PubMed Central. For those selecting our premium Author's Choice ${ }^{\mathrm{TM}}$ service, we will send your article immediately upon publishing, accelerating the accessibility of your work without the usual embargo. More details on NIH's Public Access Policy are available at http://publicaccess.nih.gov/FAQ.htm\#a1

\section{Self-Archiving}

Karger permits authors to archive their pre-prints (i.e. pre-refereeing) or post-prints (i.e. final draft post-refereeing) on their personal or institution's servers, provid ed the following conditions are met: Articles may not be used for commercial purposes, must be linked to the publisher's version, and must acknowledge the publisher's copyright. Authors selecting Karger's Author's Choice ${ }^{\mathrm{TM}}$ feature, however, are also permitted to archive the final, published version of their article, which includes copyediting and design improvements as well as citation links.

\section{KARGER}

E-Mail karger@karger.com www.karger.com
(C) 2013 S. Karger AG, Basel 


\section{Acta \\ Hæmatologica}

\section{Page Charges}

Authors are charged CHF 160.- per printed page for the first 6 pages and CHF 325.- for each additional page, including tables, illustrations, and references. 1 printed page is equal to approximately 3 manuscript pages.
Proofs

Unless indicated otherwise, proofs are sent to the corresponding author and should be returned with the least possible delay. Alterations made in proofs, other than the correction of printer's errors, are charged to the author.

\section{Reprints}

Order forms and a price list are sent with the proofs. Orders submitted after the issue is printed are subject to considerably higher prices.

\begin{tabular}{|c|c|c|c|}
\hline Entity & Abbreviation & Recommended unit & Alternative unit \\
\hline Red blood cell count & $\mathrm{RBC}$ & $\times 10^{12} / 1$ & \\
\hline White blood cell count & WBC & $\times 10^{9} / 1$ & \\
\hline Platelet count & PLT & $\times 10^{9} / 1$ & \\
\hline Reticulocyte count & RETIC & $\%$ & \\
\hline Hemoglobin & $\mathrm{Hb}$ & $\mathrm{g} / \mathrm{dl}$ & \\
\hline Hematocrit (packed cell volume) & HCT & ratio, no unit necessary & \\
\hline Mean cell volume & $\mathrm{MCV}$ & $\mathrm{fl}$ & \\
\hline Mean cell hemoglobin & $\mathrm{MCH}$ & pg & \\
\hline Mean cell hemoglobin concentration & $\mathrm{MCHC}$ & g/dl & \\
\hline Sedimentation rate & ESR & $\mathrm{mm} / \mathrm{h}$ & \\
\hline Serum vitamin $B_{12}$ & & $\mathrm{pg} / \mathrm{ml}$ & $\mathrm{pmol} / \mathrm{l}$ \\
\hline Serum folate & & $\mathrm{ng} / \mathrm{ml}$ & $\mathrm{nmol} / \mathrm{l}$ \\
\hline Serum iron & & $\mu \mathrm{g} / \mathrm{dl}$ & $\mu \mathrm{mol} / \mathrm{l}$ \\
\hline Iron-binding capacity & IBC & $\mu \mathrm{g} / \mathrm{dl}$ & $\mu \mathrm{mol} / \mathrm{l}$ \\
\hline Serum ferritin & & $\mathrm{ng} / \mathrm{ml}$ & $\mu \mathrm{g} / \mathrm{l}$ \\
\hline Transferrin & & $\mathrm{mg} / \mathrm{dl}$ & $\mathrm{g} / \mathrm{l}$ \\
\hline Serum haptoglobin & & $\mathrm{mg} / \mathrm{dl}$ & $\mathrm{g} / \mathrm{l}$ \\
\hline Fibrinogen & & $\mathrm{mg} / \mathrm{dl}$ & $\mathrm{g} / \mathrm{l}$ \\
\hline Immunoglobulin $\mathrm{G}, \mathrm{A}, \mathrm{M}$ & $\operatorname{IgG}, \operatorname{Ig} A, \operatorname{Ig} M$ & $\mathrm{mg} / \mathrm{dl}$ & $\mathrm{g} / \mathrm{l}$ \\
\hline Beta-2-microglobulin & $\beta_{2} \mathrm{~m}$ & $\mathrm{mg} / \mathrm{l}$ & \\
\hline
\end{tabular}

\section{'A collection of extraordinary essays'}

\section{GOTTFRIED SCHATZ}

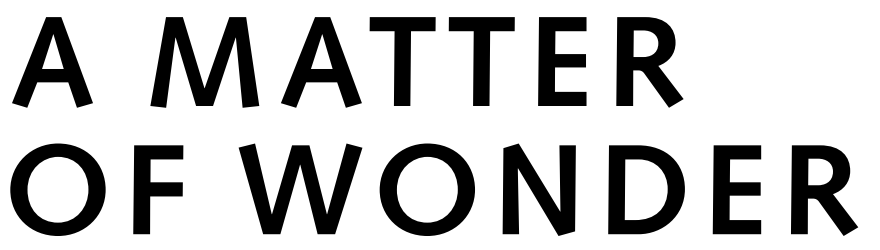

What Biology Reveals about Us, Our World, and Our Dreams

Where do we come from? Is our destiny determined by the genes we inherit? In this book Gottfried Schatz, the world-renowned biochemist and co-discoverer of mitochondrial DNA, gives lucid - albeit often surprising - answers to universal questions and takes the reader on a fascinating journey of discovery across the boundaries of scientific disciplines. With passion and a keen sense of wonder he draws on philosophy, cultural history and art to formulate his reflections on the mysteries of life. His essays will appeal not only to scientists but to all inquisitive minds, regardless of educational and professional background.

\section{KARGER}

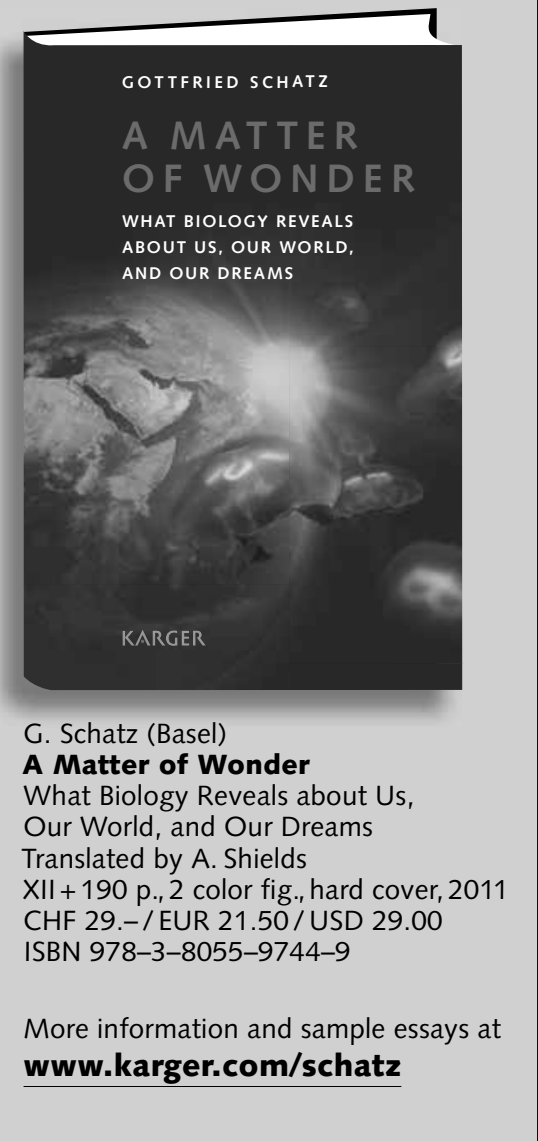

KI11274 
ISSN Print Edition: 0001-5792

ISSN Online Edition: 1421-9662

Journal Homepage: www.karger.com/aha

Publication Data: 'Acta Haematologica' is published 8 times a year. Volumes 129-130, each with 4 issues, appear in 2013

Copyright: (c) 2013 S. Karger AG, Basel (Switzerland). All rights reserved. No part of this publication may be translated into other languages, reproduced or utilized in any form or by any means, electronic or mechanical, including photocopying, recording, microcopying, or by any information storage and retrieval system, without permission in writing from the publisher or, in the case of photocopying, direct payment of a specified fee to the Copyright Clearance Center.

Disclaimer: The statements, opinions and data contained in this publication are solely those of the individual authors and contributors and not of the publisher and the editor(s). The appearance of advertisements in the journal is not a warranty, endorsement, or approval of the products or services advertised or of their effectiveness, quality or safety. The publisher and the editor(s) disclaim responsibility for any injury to persons or property resulting from any ideas, methods, instructions or products referred to in the content or advertisements.
Subscription Rates: Subscriptions run for a full calendar year. Prices are given per year. Personal subscription:

Print or Online

CHF 1460.-

EUR 1178.-

USD 1446.00

Print+Online combined CHF 1556.-

EUR 1256.-

postage and handling (added to print and print+online)

57.60 Europe, CHF 83.20 Overseas

EUR 44.80

USD 76.80

Institutional subscription

Print or Online

Print+Online combined

CHF 2920.-

EUR 2354.-

CHF 3212.-

USD 2892.00

EUR 2590.-

postage and handling (added to print and print+online)

CHF 72.- Europe, CHF 104.- Overseas

EUR 56.-

USD 96.00

Airmail surcharge: CHF 70.00 / USD 66.00

Discount subscription prices:

European Haematology Association

International Society of Haematology
Back Volumes and Single Issues: Information on availability and prices of single print issues and print or electronic back volumes can be obtained from Customer Service atservice@karger.com.

Bibliographic Indices: This journal is regularly listed in bibliographic services, including Current Contents ${ }^{\circledR}$ and PubMed/MEDLINE.

Photocopying: This journal has been registered with the Copyright Clearance Center (CCC), as indicated by the code appearing on the first page of each article. For readers in the US, this code signals consent for copying of articles for personal or internal use, or for the personal or internal use of specific clients, provided that the stated fee is paid per copy directly to

Copyright Clearance Center Inc.

222 Rosewood Drive

Danvers, MA 01923 (USA)

A copy of the first page of the article must accompany payment. Consent does not extend to copying for general distribution, for promotion, for creating new works, or for resale. In these cases, specific written permission must be obtained from the copyright owner,

S. Karger AG, P.O. Box

CH-4009 Basel (Switzerland).
Change of Address:

Both old and new address should be sent

to the subscription source.

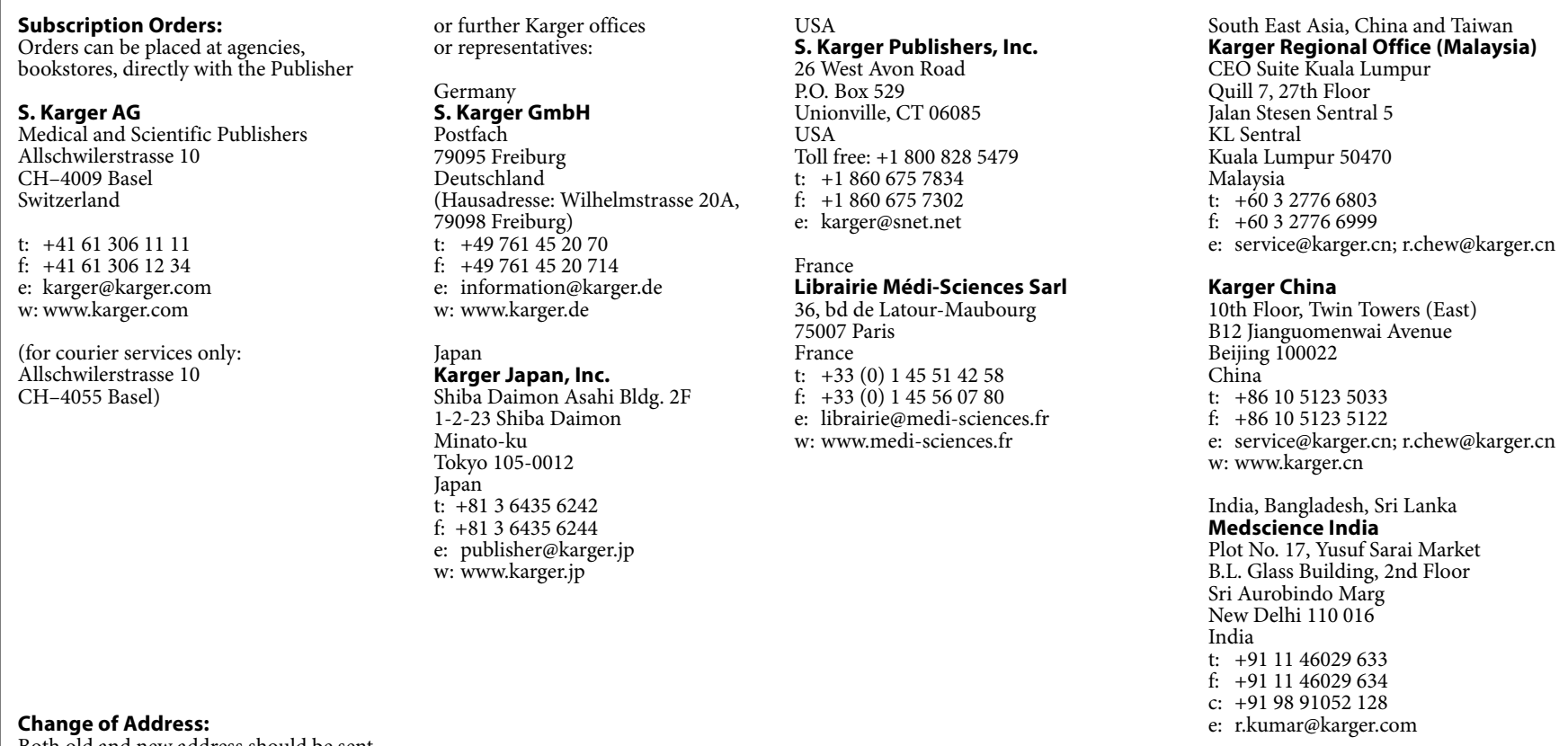

Karger China

10th Floor, Twin Towers (East)

w: www karger.cn

India, Bangladesh, Sri Lank

c: +919891052128

e: r.kumar@karger.com

\section{KARGER}

E-Mail karger@karger.com www.karger.com
(C) 2013 S. Karger AG, Basel

The Guidelines for Authors are available at: www.karger.com/aha_Guidelines 


\section{Contents}

See the journal website for contents

KARGER Basel $\bullet$ Freiburg $\cdot$ Paris $\bullet$ London $\bullet$ New York $\cdot$ New Delhi $•$ Bangkok Beijing $\cdot$ Tokyo $\cdot$ Kuala Lumpur $\cdot$ Singapore $\bullet$ Sydney 


\section{Acta Hæmatologica}

(Continued from back cover)

217 Self-Limited Effusion Large B-Cell Lymphoma: Two Cases of Effusion Lymphoma Maintaining Remission after Drainage Alone

Nakatsuka, S. (Amagasaki); Kimura, H. (Amagasaki/ Toyonaka); Nagano, T.; Fujita, M.; Kanda, T.; Iwata, T.;

Hashimoto, K. (Amagasaki)

Brief Communications

135 Absence of Merkel Cell Polyomavirus in Monocytic Leukemias

Hashida, Y.; Imajoh, M.; Taniguchi, A.; Kamioka, M.;

Daibata, M. (Kochi)

138 Inhalation as a Source of Iron in Secondary Iron Overload

Nicolson, P.L.R.; Doherty, M.J.; Cooper, S.C.; Neilson, J. (Birmingham)
150 Measurement of Thrombin in Different Matrices: Whole Blood, Platelet-Rich and Platelet-Poor Plasma Using Fluorogenic Substrate ZGGR-AMC

Mitchell, J.A. (Debrecen/Guildford); Nagymihaly, R.;

Uhrinyi, O.M.; Harsfalvi, J. (Debrecen)

172 Pulmonary Artery Pressure Correlates Directly with Spleen Volume in Non-Splenectomized Hemoglobin E/ $\boldsymbol{\beta}$-Thalassemia Patients

Atichartakarn, V.; Chuncharunee, S.; Yamwong, S.;

Yingchoncharoen, T.; Jongjirasiri, S.; Archararit, N.;

Udomsubpayakul, U. (Bangkok)

176 Acute Promyelocytic Leukemia with a Rare PML Exon 4/RARA Exon 3 Fusion Transcript Variant Oh, S.J.; Park, T.S. (Seoul); Lee, J.Y. (Yongin); Mun, Y.C.; Seong, C.M. (Seoul); Marschalek, R.; Meyer, C. (Frankfurt); Chung, W.S.; Huh, J. (Seoul)

222 Erratum 


\section{Actramatologica}

\section{Editorial Comments}

192 Treating Chronic Myeloid Leukemia in the Era of Tyrosine Kinase Inhibitors

Gale, R.P.; Goldman, J.M. (London)

196 Adult Acute Lymphoblastic Leukemia: A Cancer with No Standard of Care

Douer, D. (New York, N.Y.)

Original Papers

153 Pulmonary Hypertension Risk in Patients with Hemoglobin H Disease: Low Incidence and Absence of Correlation with Splenectomy

Yin, X.-L.; Zhang, X.-H. (Nanning); Wu, Z.-K. (Beijing); Zhao, D.-H.; Zhou, Y.-L.; Yu, Y.-H.; Liu, T.-N. (Nanning);

Fang, S.-P. (Beijing); Zhou, T.-H.; Wang, L.; Huang, J. (Nanning)

160 Soluble Human Leukocyte Antigen G Molecule Expression in Allogeneic Hematopoietic Stem Cell Transplantation: Good Predictor of Acute Graft-versus-Host Disease

Liu, H.; Chen, Y.; Xuan, L.; Wu, X.; Zhang, Y.; Fan, Z.; Huang, F.; Zhang, X.; Jiang, Q.; Sun, J.; Liu, Q. (Guangzhou)

181 Clinical and Laboratory Significance of Defective P2Y 12 Pathway Function in Patients with Myeloproliferative Neoplasms: A Pilot Study

Chang, H.; Shih, L.-Y. (Taoyuan); Michelson, A.D.

(Boston, Mass.); Dunn, P. (Taoyuan); Frelinger, A.L.

(Boston, Mass.); Wang, P.-N.; Kuo, M.-C.; Lin, T.-L.;

Wu, J.-H.; Tang, T.-C. (Taoyuan)

199 Hyper-CVAD Regimen in Routine Management of Adult Acute Lymphoblastic Leukemia: A Retrospective Multicenter Study

Buyukasik, Y.; Acar, K. (Ankara); Kelkitli, E. (Samsun); Uz, B. (Ankara); Serefhanoglu, S. (Istanbul); Ozdemir, E.;

Pamukcuoglu, M. (Ankara); Atay, H. (Samsun); Bektas, O.;

Sucak, G.T. (Ankara); Turgut, M. (Samsun); Aksu, S.; Yagci, M.; Sayınalp, N.; Ozcebe, O.I.; Goker, H.; Haznedaroglu, I.C.

(Ankara)
206 Peripheral Blood Stem Cell Transplantation from Human Leukocyte Antigen-Matched Sibling Donors and Unrelated Donors in Acute Myeloid Leukemia Patients Kim, H.-J.; Kim, S.-Y.; Lee, M.H.; Min, W.-S. (Seoul)

Case Reports

127 B-Lymphoblastic Leukemia/Lymphoma Associated with $\mathrm{t}(8 ; 13)(\mathrm{p} 11 ; \mathrm{q} 12) / Z M Y M 2$ (ZNF198)-FGFR1: Rare Case and Review of the Literature

Trimaldi, J.; Carballido, E.M.; Bowers, J.W. (Tampa, Fla.); Anguiano, A.L.; Zhang, Z.J. (San Juan Capistrano, Calif.); Shah, B.D.; Bruno, S.; List, A.F.; Moscinski, L.C.; Grady, T.; Agosti, S.J.; Kang, L.; Zhang, L. (Tampa, Fla.)

142 Development of JAK2V617F-Positive Polycythemia Vera after Chemotherapy-Induced Remission of Primary Central Nervous System Diffuse Large B Cell Non-Hodgkin's Lymphoma: A Case Report and Review of the Literature

Elli, E.M.; Belotti, A.; Cecchetti, C.; Realini, S.; Fedele, M.; Parma, M.; Pogliani, E.M. (Monza)

146 Waldenström's Macroglobulinemia Associated with Serum Amyloid A Protein Amyloidosis: Pitfalls in Diagnosis and Successful Treatment with Melphalan-Based Autologous Stem Cell Transplant Muzaffar, J.; Katragadda, L.; Haider, S.; Abdallah, A.-O.; Anaissie, E.; Usmani, S.Z. (Little Rock, Ark.)

169 Intrapericardial and Intrapleural Administration of Rituximab to a Patient with Marginal Zone Lymphoma Boguradzki, P.; Drozd-Sokolowska, J.E.; Wieczorek, J.; Kowalik, R.; Starczewska, M.; Krol, M.; Kobylecka, M.; Opolski, G.; Wiktor-Jedrzejczak, W. (Warsaw)

188 Precursor B-Cell Lymphoblastic Leukemia with Surface Immunoglobulin Light Chain Expression in 2 Chinese Patients

Liu, Y.; Zhai, Y.; Zhang, Y.; Cheng, W.; Li, Y. (Zhengzhou)

(Continued on inside back cover) 